\title{
IMPLICATIONS OF INVASIVE SHRUB GORSE (ULEX EUROPAEUS L.) ERADICATION PROGRAMS IN HORTON PLAINS NATIONAL PARK, SRI LANKA: A CASE STUDY FROM A TROPICAL ISLAND
}

\author{
JAYASEKARA, D. ${ }^{1,2,3}$ - ChANDRASIRI, P. H. S. P. ${ }^{2,3}$ - DhaRMARATHNE, W. D. S. C. ${ }^{1,3}-$ \\ PRABHATH, M. C. ${ }^{1,3}-$ MaHAUlPATHA, W. A. D. ${ }^{1,3^{*}}$ \\ ${ }^{I}$ Department of Zoology, Faculty of Applied Sciences, University of Sri Jayewardenepura, \\ Gangodawila, Nugegoda, Sri Lanka
}

${ }^{2}$ Faculty of Graduate Studies, University of Sri Jayewardenepura, Gangodawila, Nugegoda, Sri Lanka

${ }^{3}$ Wildlife Circle, Department of Zoology, Faculty of Applied Sciences, University of Sri Jayewardenepura, Gangodawila, Nugegoda, Sri Lanka

*Corresponding author e-mail: mahaulpatha@sjp.ac.lk; phone: +94-71-825-1516

(Received $20^{\text {th }}$ Apr 2021; accepted $8^{\text {th }}$ Jul 2021)

\begin{abstract}
Alien invasive species are a significant threat to biodiversity and ecosystems in nonnative geographical ranges. Ulex europaeus is one such shrub introduced to the montane grasslands of Sri Lanka. We conducted this study with the objective of evaluating the U. europaeus removal programs focusing on both positive and negative impacts that arose. Three months of pre-removal and three months each of two post-removal time periods were selected for sampling. We evaluated the changes in the density of $U$. europaeus, Calotes nigrilabris, spatiotemporal variation of vegetative structure and pollinator abundance. Initially, the removal of $U$. europaeus was mostly successful in terms of reduced shrub density. However, the prevalence and emergence of live shrubs after the removal program raises concerns regarding the viability of the project. Furthermore, the drastic population density reduction of endemic and threatened lizard $C$. nigrilabris following the removal of $U$. europaeus can be considered a negative impact of high conservation concern. However, we observed an increase in pasture availability and re-establishment of natural vegetative structure. It can be concluded that proper knowledge regarding the invasive species and understanding their ecological linkages is important for the success of management programs. Continuous and long term, control and monitoring are recommended.
\end{abstract}

Keywords: invasion ecology, plant population and community dynamics, alien invasive species, grassland habitat, habitat management, endemic fauna, adaptation

\section{Introduction}

An alien invasive species can be defined as "a species introduced into a habitat and whose establishment and spread threatens the ecosystem, habitat or species with economic or environmental harm" (McNeely, 2001; Bambaradeniya, 2002). The impact these species have on ecosystems is difficult to quantify and integrate with a holistic and meaningful approach (Byers et al., 2002; Barney et al., 2013). From a conservation and ecosystem service protection perspective, ecological consequences should be given more attention (MA, 2005). Gerber et al. (2008) mentioned the importance of studies addressing multiple trophic levels (plant species, herbivores, predators, pollinators) are likely to yield additional insight into how and under which conditions invasive weeds alter ecosystem structures and processes (James et al., 2010). 
The success or failure of invasive species management programs may depend on the amount of knowledge available regarding the species of interest as well as its ecological linkages. The invasive nature of these alien species may tend to establish novel ecological linkages in the new environments which were absent in their native range leading to novel environments, species combinations and altered ecosystem function (Hobbs et al., 2009). The breakdown of biogeographic barriers through the global human transport of species has increased the pace of this phenomenon and especially the spreading of invasive plants (Lodge et al., 2006; Nentwig, 2007; Hobbs et al., 2009). The highly competitive nature of invasive plants results in consuming more resources than native plants (Williams and West, 2000). Outcompeting the native plants for pollinators (Williams and West, 2000; Morales and Traveset, 2009) reduces the reproductive success of native plants (Morales and Traveset, 2009). In occasions, these invasive species may change the abundance and fitness of animal species (Vilà et al., 2011). However, these changes may include both adverse as well as facilitative impacts to the native species (Rodriguez, 2006). Therefore, eradication of invasive species once established in a nonnative landscape may trigger unexpected consequences. Furthermore, selection of the most viable and effective methods will enhance the success of management intervention.

The evergreen shrub Ulex europaeus commonly known as "Gorse" (Fig. 1b), native to Western Europe-Atlantic coast of Europe (Clements et al., 2001; Hill et al., 2001; Hill and Gourlay, 2002; Bowman et al., 2007; Atlan et al., 2010; Christina et al., 2020), has been identified as one of the 100 worst alien species of the world (Lowe et al., 2000). It is a thorny leguminous perennial shrub that belongs to family Fabaceae (Hill et al., 2000) which grows up to $7 \mathrm{~m}$ in height (Lee et al., 1986; Mbatha, 2016). The stem of the plant is armed with conspicuous spines to deter herbivores (Mbatha, 2016). $U$. europaeus produces acicular evergreen leaves that develop to scales or spine-like phyllodes with maturity (Viljoen and Stoltsz, 2007; Mbatha, 2016). This plant produces pea-like dark yellow flowers and ciliated green pods that become dark brown at maturity (Viljoen and Stoltsz, 2007; Ireson et al., 2008; Mbatha, 2016). Each pod contains 5-9 brown seeds (Clements et al., 2001). U. europaeus plants can live for up to 29 years (Lee et al., 1986) and large seed banks can be observed in infected areas (Gonzalez et al., 2010; Mbatha, 2016). Seeds of $U$. europaeus can remain viable for more than 10 years in the soil (Hill et al., 2001) or even a couple of decades (Hermann and Newton, 1968; Zielke et al., 1992; Clements et al., 2001; Hill et al., 2001) and the optimum germination temperature is at $10-15^{\circ} \mathrm{C}$ (Sixtus et al., 2003).

The geographical distribution of $U$. europaeus extends to more than 50 countries/island groups throughout the world with climates similar to its native range in Western Europe (Christina et al., 2020). Christina et al. (2020) describe the potential niche expansion of $U$. europaeus. In most of the nonnative regions this species has become invasive including countries such as Australia, Brazil, Canada, Chile, Germany, New Zealand, India, Spain, and the United States (Holm et al., 1977; Gaynor and MacCarter, 1981; Hoshovsky, 1989; Clements et al., 2001; Leary et al., 2006; Mbatha, 2016; Christina et al., 2020). Interestingly, in the central mountains of the tropical Indian Ocean island Sri Lanka, U. europaeus has found a home in an unlikely place. Horton Plains National Park (HPNP) in the montane region of the island includes areas of grassland where $U$. europaeus is present. HPNP, being a place of high biological diversity and endemicity, face considerable consequences by the spread of this invasive plant (Bambaradeniya, 2002) as well as from its eradication programs. 

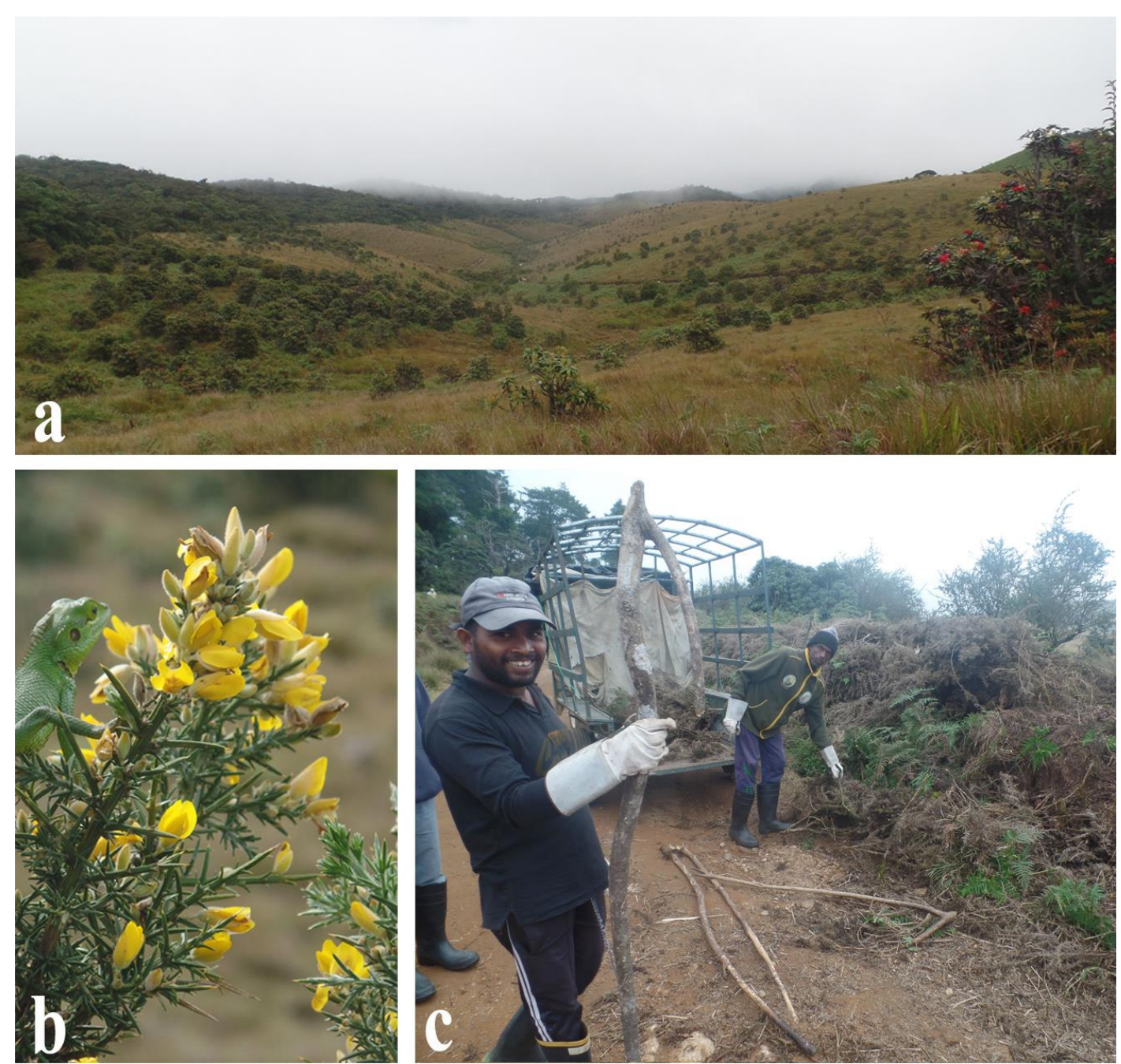

Figure 1. (a) Grassland habitat of HPNP. (b) U. europaeus commonly known as "Gorse" with thorny leaves and yellow flowers. (c) U. europaeus removal programs that are being conducted with the involvement of human labor uprooting the shrubs and burning the vegetative parts

(16.10.2016)

HPNP is a National Park situated in the highest elevation of the island (1750$2384 \mathrm{~m}$ a.s.1.) with distinct weather patterns, cold climatic conditions and highly range restricted endemic flora and fauna. The average temperature of the area is around $15^{\circ} \mathrm{C}$ and gets to near zero levels at times according to the report of Department of Wildlife Conservation (DWC, 2007). This highland plain is a mosaic of montane cloud forest patches and scattered grasslands. Grassland habitat ('wet patana') (Fig. la) is one of the prominent habitat types of HPNP. This habitat dominated by native species like Chrysopogon nodulibarbis, Garnotia exaristata, Andropogon polyptychos and Dwarf Bamboo Arundinaria densifolia (Gunatilleke and Gunatilleke, 1986; DWC, 2007; Pethiyagoda, 2012; Somaweera et al., 2012) have lately been invaded by fast spreading alien invasive species like European Gorse (U. europaeus), Aristea ecklonii, Ageratina riparia and Austroeupatorium inulifolium (Pethiyagoda, 2012; Somaweera et al., 2012; De Alwis et al., 2019). The native endemic flowering plant Rhododendron arboreum subsp. zeylanicum ("Maha-Rathmal") is another common plant that can be observed 
scattered throughout the grasslands (Gunatilleke and Gunatilleke, 1986). The unique weather condition that prevails in the area creates a home away from home for the opportunistic and notorious Gorse plant. HPNP is the only locality (33 $\mathrm{km}^{2}$ area) in the country that sustain a population of $U$. europaeus. Due to the spreading of the invasive $U$. europaeus, the integrity of species composition and community structure of these montane grasslands remain uncertain even after the eradication programs (Fig. 1c) of 2016-2017 (De Alwis et al., 2019) (the first large scale attempt following several unsuccessful eradication programs in the past). U. europaeus removal was conducted using a large amount of human labor hours uprooting the shrubs and burning the vegetative parts in successive time periods. The previous programs were mostly onetime efforts conducted in a haphazard manner (Marambe et al., 2001; Somaweera et al., 2012).

Since, the introduction of $U$. europaeus into the area by the British colonists in 1888 (Wijesundera, 1999; Pethiyagoda, 2012; Somaweera et al., 2012) several forest and grassland faunal species got attracted to the plant as behavioral adaptations. In some of its native ranges a bimodal flowering onset has been observed in $U$. europaeus (Atlan et al., 2010). However, in this tropical montane climate, $U$. europaeus has been observed flowering almost throughout the year in the absence of seasonal variation in climate. This phenomenon attracted several pollinator species as well as their predators to this plant. The flowers of this plant do not produce nectar. However, the pollen of $U$. europaeus are able to attract some insects with their beneficial properties (Atlan et al., 2010). Pollinator species include mainly "bee" species while one of their main predators; the Black-lipped agama/lizard Calotes nigrilabris (Fig. 2a, b) (Somaweera and Somaweera, 2009; Somaweera et al., 2012; Pethiyagoda, 2012; De Silva and Ukuwela, 2017), and several bird species like Dull blue fly catcher Eumyias sordidus and Pied-Bushchat Saxicola caprata were observed to be frequenting the $U$. europaeus shrubs to prey upon the insect pollinators (Dharmarathne and Mahaulpatha, 2018). Somaweera et al. (2012) investigated the beneficial properties of $U$. Europeaus towards native $C$. nigrilabris. Bees use pollen of $U$. europaeus to feed their larvae which in turn strengthens the hives, and increases overall honey production (Hill and Sandrey, 1986).

The consequences that were left unanswered by the rapid eradication of this invasive plant are yet to be evaluated. Therefore, we conducted this research to evaluate the impact of $U$. europaeus eradication programs on the balance of native faunal and floral assemblage specifically considering the impact on faunal species that had been attracted to the beneficial properties of the plant. Furthermore, the success or failure of the program was also evaluated comparing the pre-removal and post-removal time periods. We used several quantitative parameters, in the form of density, abundance, and objectoriented spatial analysis, for the spatio-temporal evaluation of the changes that occurred parallel to the $U$. europaeus eradication programs. The results will indicate the amount of ecological resilience towards the human intervened (partially) alterations to the grassland habitats of HPNP.

\section{Methodology}

The HPNP (3300 ha) comprises of a combination of Tropical Montane Cloudforests and Wet "Patana" Grasslands (DWC, 2007; Pethiyagoda, 2012). The grassland habitat is arranged in a patchy distribution throughout the park. Since, U. europaeus 
has invaded only the areas with grasses thus far; we focused our study only on the grassland habitats. We divided the park area into $1-\mathrm{km}^{2}$ plots with a grid in Arc GIS (Esri, Redlands, USA). Based on the preliminary surveys, five plots with areas highly invaded by U. europaeus were selected for the study (Fig. 3). We carried out sampling in three specific time periods in three different years. The first sampling period was named as pre-removal period (before the removal of $U$. europaeus; January-March 2016). The second and third sampling periods were named as post-removal period 1 (after the removal of U. europaeus; January-March 2018) and post-removal period 2 (after the regeneration of vegetation; January-March 2021). We selected the same month ranges in all three years to reduce the bias caused by seasonal variability. The first phase of U. europaeus removal programs was started in October 2016 and ended in April 2017.
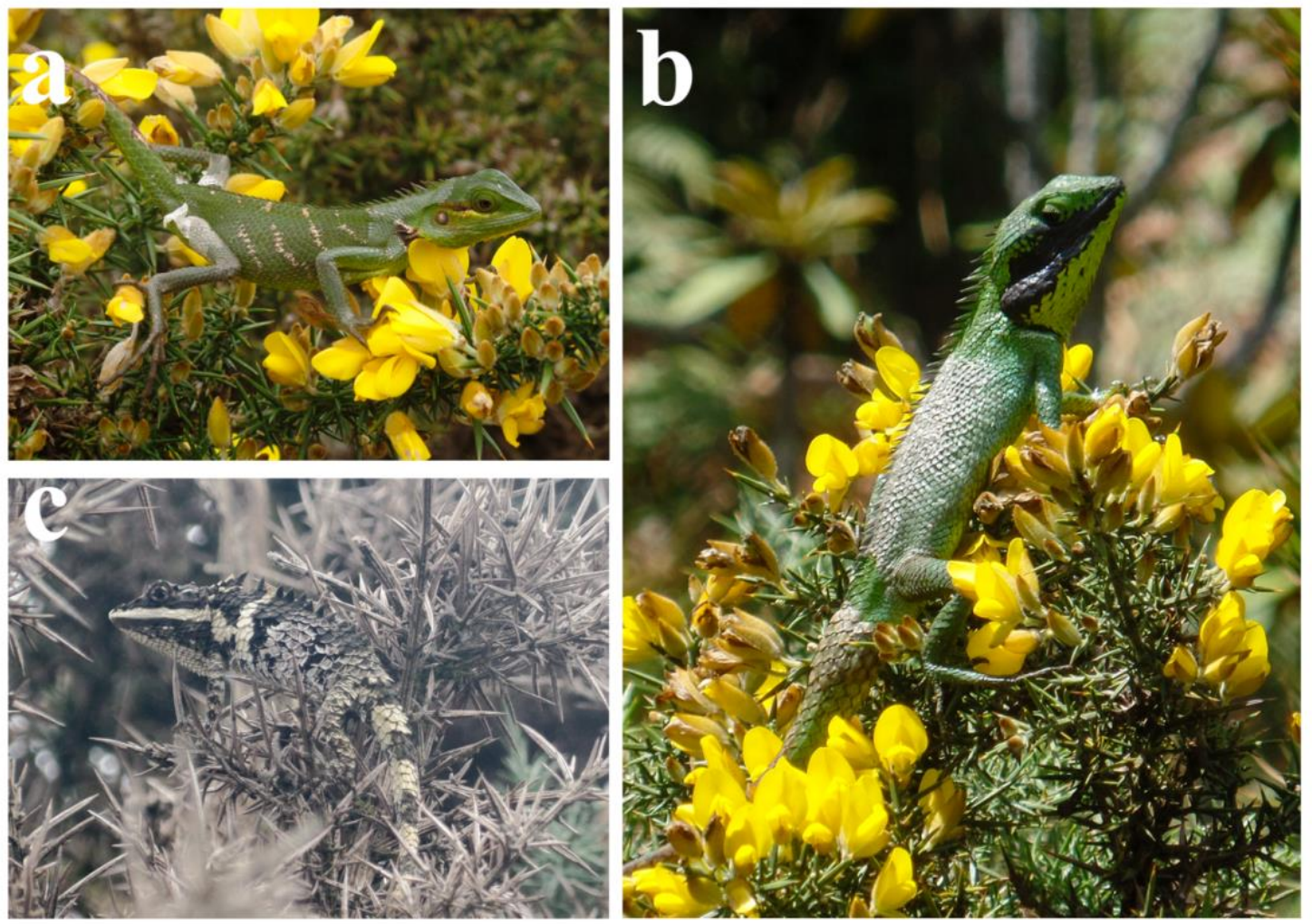

Figure 2. (a) A Ca. nigrilabris adult female waiting for insect prey among the U. europaeus flowers. (b) An adult Ca. nigrilabris male on an U. europaeus shrub. (c) A male Co. ceylanica camouflaged among the dead branches of U. europaeus

\section{Temporal variation of $U$. europaeus density}

Distance based visual detection line-transect (Buckland et al., 2000, 2001, 2004; Kissa and Sheil, 2012) method of density estimation was followed to estimate the $U$. europaeus densities. Within each selected plot, six line transects of $100 \mathrm{~m}$ were surveyed by a single individual at a time. While walking on transects, the perpendicular distance to each visible shrub of $U$. europaeus was measured using a measuring tape. Multi-stemmed shrubs were considered as one individual plant (Kissa and Sheil, 2012). 


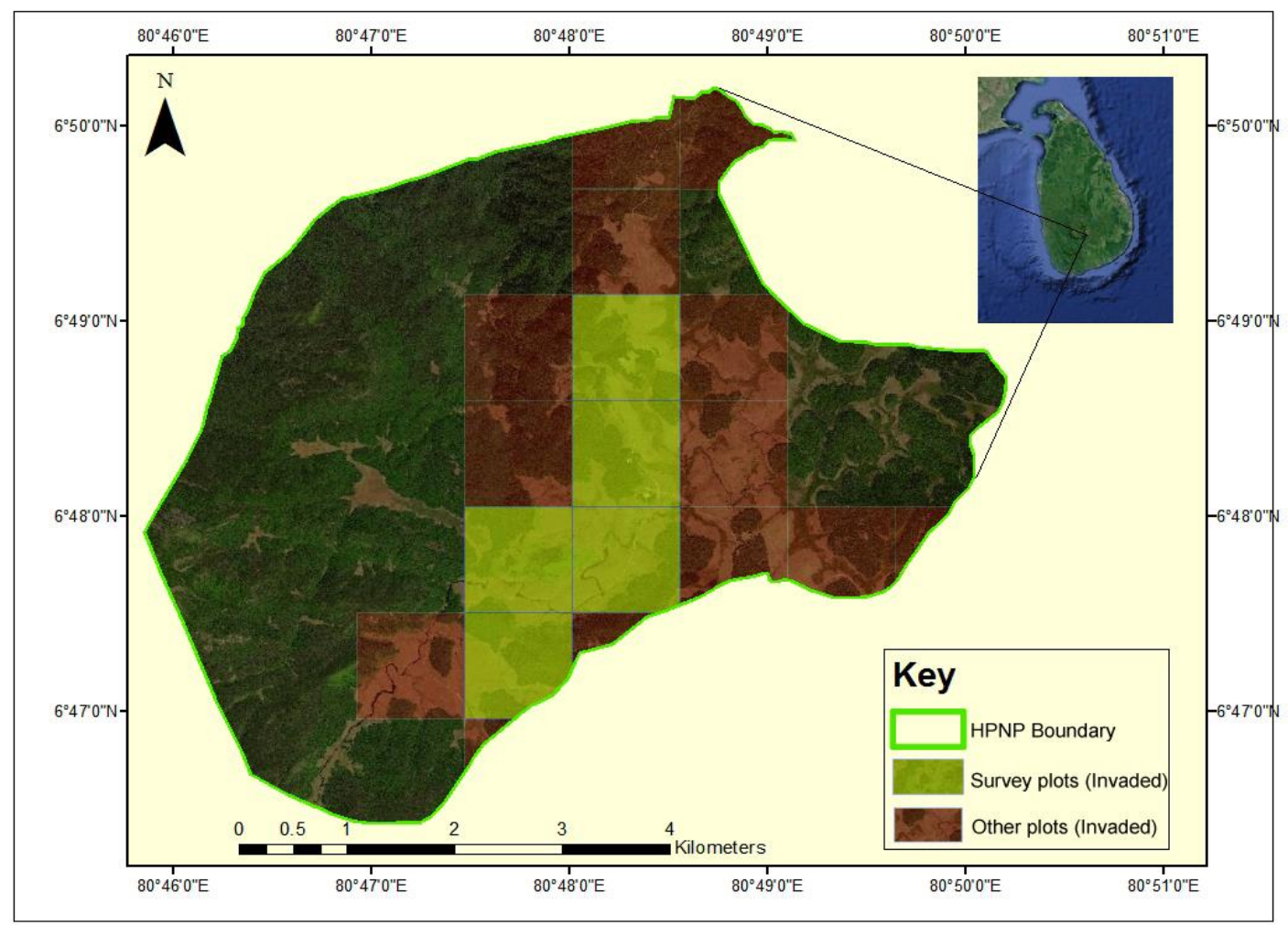

Figure 3. Map of HPNP with U. europaeus invaded area represented by $1 \times 1 \mathrm{~km}$ plots. In light green color are the survey plots

\section{Temporal variation of $C$. nigrilabris density}

Distance based visual detection line-transect (Buckland et al., 2000, 2001, 2004; Karsten et al., 2009) method of density estimation was followed to estimate the $C$. nigrilabris densities. In each plot, six $100 \mathrm{~m}$ transects were laid and traversed for $C$. nigrilabris census. The perpendicular distance from the transect line for each lizard sighted was recorded. The most active time of the day for C. nigrilabris (9 a.m. - 10 a.m.) (Jayasekara et al., 2019) was selected for sampling of lizards.

$U$. europaeus plant and $C$. nigrilabris density were calculated separately for the three study years (pre-removal, post-removal 1 and post-removal 2 of $U$. europaeus) using the software package "DISTANCE 7.1" (Thomas et al., 2010).

\section{Temporal variation of insect pollinator abundance}

Only the insect orders, Hymenoptera and Lepidoptera were targeted during the sampling, which are generally the most dominant pollinator taxons (Losey and Vaughan, 2006; McCravy, 2018; Ollerton et al., 2011). Furthermore, insect trapping methods that attract a large number of insects of different taxa and those which cause insect mortality were not performed due to the high sensitivity and protection status of the study site. We performed aerial netting (Grootaert et al., 2010; McCravy, 2018) at three points within each transect to trap the aerial insect pollinators. The net ring was 36 $\mathrm{cm}$ with a $90 \mathrm{~cm}$ handle. Ten aerial sweeps were performed at one point in a horizontal orientation. Insects were identified to the species level when possible and to 
recognizable taxonomic units when not (Harris et al., 2004). However, only the counts of insects that belonged to the Orders, Hymenoptera and Lepidoptera were obtained for the analysis. All insects were released immediately following the identification and counting.

\section{Quantification of spatiotemporal variation of vegetation structure using oblique photo-point images}

We used the software package eCognition V9.0 (Baatz et al., 2004; eCognition Developer, 2014) to map vegetation structure using terrestrial-based photo-point (PP) images (Michel et al., 2010) from three separate dates (07.02.2016, 27.04.2017, 27.06.2020) selected independent of density surveys. Three photographs of a single PP, which we identified to have a high abundance of $U$. europaeus in the pre-removal period, were analyzed to obtain the percentage coverage of each vegetation type. The software package eCognition is an object-oriented classifier in which we performed two successive steps: image segmentation and image object classification. Object-oriented classifications rely on both the spectral information and the spatial information contained in digital images (Baatz, 2000).

We used a scale parameter of 100-150 which defines the number of segments the image is divided into based on color. For the homogeneity criterions, a shape factor of 0.2 and a compactness of 0.5 were applied for all three images. Since variations in color, rather than shape is considered as best factor to define patterns in the image (Michel et al., 2010), the classifications were performed mainly using the color of the objects (i.e., object mean spectral values for red, green and blue layers). Sample classification which was given manually as an input to the software was validated by visual comparison with the original photographs. The main object categories included in the analysis were; Rhododendron arboreum, U. europaeus, grasses, Pteridium spp., other vegetation and sky. Based on the samples provided, the software extrapolated the classifications to entire images. Prior to the exporting of the final output, misclassified objects were manually reassigned to their correct classes. Classified images were exported as portable network graphics (.png) files. The relative proportion of each classified object category was calculated following the method used by Gaitonde et al. (2018) using an online TinEye (C) color extraction application (Cruz et al., 2016) based on the RGB values of all colors constituting the image and is detailed here at https://services.tineye.com/developers/multicolorengine/methods/extract_image_colors. html.

\section{Results}

When the pre-removal and post-removal 1 densities of $U$. europaeus were considered, there was a drastic decline from 193.64 plants/ha (January-March 2016) to 4.69 plants/ha (January-March 2018) in the U. europaeus density after the eradication programs conducted in 2016-2017 (Table 1). However, the most recent field surveys yielded a higher density value of 25.03 plants/ha (January-March 2021). Meanwhile, in the pre-removal period, the density of the grassland population of $C$. nigrilabris was 27.69 individuals/ha and it is showing a steep decline having a density of only 5.4 individuals/ha in 2018 post-removal 1. Despite the relative increase in $U$. europaeus density in year 2021 post-removal 2, C. nigrilabris density has further decreased to an alarming figure of 3.96 individuals/ha. Pollinator abundance was relatively higher 
(Hymenoptera, 315; Lepidoptera, 58) in the pre-eradication period. After the removal of $U$. europaeus, only the order Hymenoptera displayed a considerable decline in abundance in post-removal 1 period (61) while the Lepidoptera abundances were more or less closer to the pre-removal figure. However, in post-removal 2 sampling period, we observed an increase in Hymenoptera abundance. Hymenoptera bee pollinators included the Giant honey bee Apis dorsata (Fig. 4a) and Asian honey bee Apis cerana (Fig. 4b). Pea blue Lampides boeticus (Fig. 4c) was the most common butterfly species observed near the flowers of $U$. europaeus.
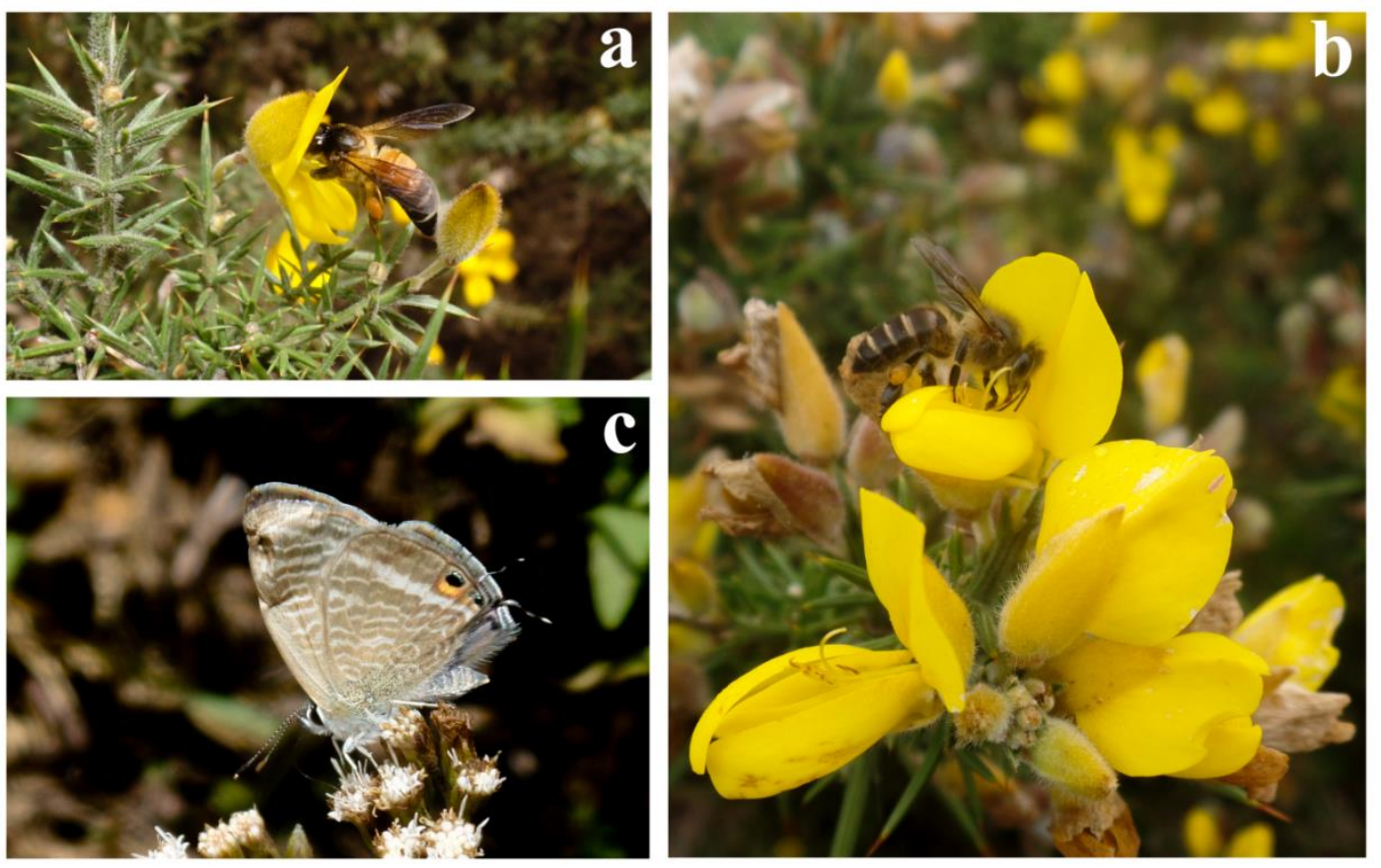

Figure 4. (a) A Giant honey bee Apis dorsata gathering pollen from the yellow flowers of $U$. europaeus. (b) An Asian honey bee Apis cerana gathering pollen from the yellow flowers of $U$. europaeus. (c) A Pea Blue Lampides boeticus, one of the few butterfly species observed at the U. europaeus shrubs

When PP images were compared, in February 2016 (pre-removal period) the proportion $U$. europaeus was a high percentage of $39.6 \%$ of the total image objects (Fig. 5). It was 0\% in April 2017 (just after the removal programs) (Fig. 6) as well as in June 2020 (three years after the removal programs) (Fig. 7). The percentage of $R$. arboretum which was 20.7 in February 2016 was observed to be increased to $40.7 \%$ and $38.8 \%$ respectively in 2017 and 2020 following the removal programs. Grass cover which was initially reduced in April 2017 (17.5\%) probably as a result of the $U$. europaeus uprooting process, had been increased to $32.3 \%$ by June 2020 . The bare ground which was exposed during the uprooting of U. europaeus dropped from a high value of $26.8 \%$ to $1 \%$ by 2020 in the area analyzed by PP method consequently. However, a significant spread of the possibly invasive Pteridium spp. plants was visible in the June 2020 PP analysis image which accounted for $11.3 \%$ of the image objects. The visible percentage of sky and the proportions of other vegetation types (mostly Dwarf Bamboo A. densifolia) displayed little spatiotemporal variations among the three analyzed images. 
Table 1. Comparison of pre-removal and post-removal densities of $U$. europaeus, $C$. nigrilabris and pollinator abundance

\begin{tabular}{|c|c|c|c|c|}
\hline \multirow[b]{2}{*}{ Taxon } & \multirow[b]{2}{*}{ Parameter } & \multicolumn{3}{|c|}{ Time period } \\
\hline & & $\begin{array}{l}2016 \text { (January- } \\
\text { March) } \\
\text { (Pre-removal) }\end{array}$ & $\begin{array}{l}2018 \text { (January- } \\
\text { March) } \\
\text { (Post-removal 1) }\end{array}$ & $\begin{array}{l}2021 \text { (January- } \\
\text { March) } \\
\text { (Post-removal 2) }\end{array}$ \\
\hline \multirow{4}{*}{ U. europaeus } & Density (Plants/ha) & 193.64 & 4.69 & 25.03 \\
\hline & D LCL (Plants/ha) & 71.97 & 2.54 & 14.43 \\
\hline & D UCL (Plants/ha) & 570.97 & 8.68 & 43.4 \\
\hline & $\mathrm{ESW}(\mathrm{m})$ & 3.89 & 4.62 & 3.36 \\
\hline \multirow{4}{*}{ C. nigrilabris } & Density (individuals/ha) & 27.69 & 5.4 & 3.96 \\
\hline & D LCL (individuals/ha) & 17.82 & 2.9 & 1.87 \\
\hline & D UCL (individuals/ha) & 43.02 & 10.07 & 8.25 \\
\hline & ESW (m) & 4.6 & 3.7 & 4.49 \\
\hline Hymenoptera & Abundance & 315 & 61 & 92 \\
\hline Lepidoptera & Abundance & 58 & 53 & 48 \\
\hline
\end{tabular}

D-Density, given as individuals or plants per hectare, D LCL-Lower Confidence Limit of density, D UCL- Upper Confidence Limit of density, ESW- Effective Stripe Width
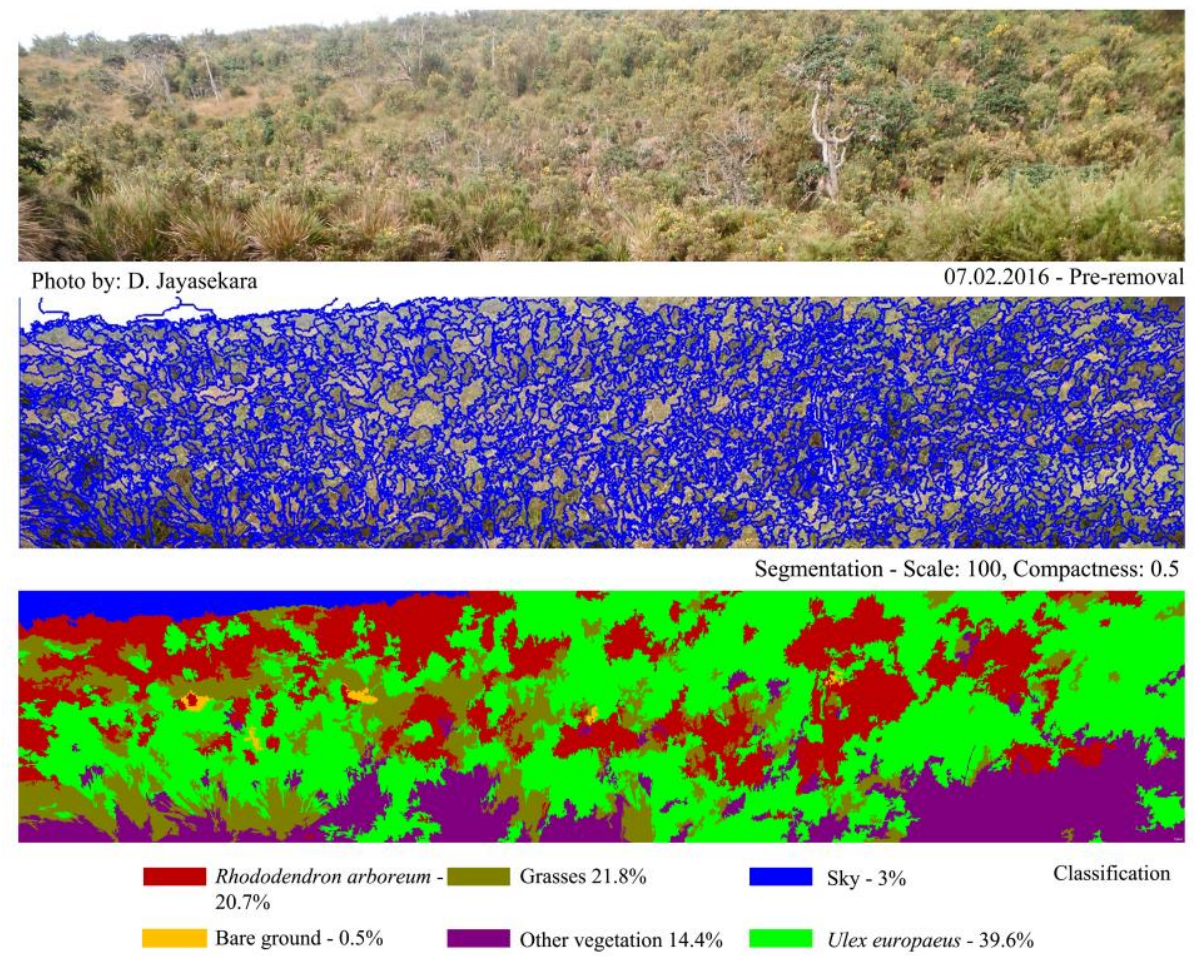

Figure 5. Photo-point (PP) images and results from image segmentation (multiresolution) and object classification using the object-oriented techniques with the software eCognition Developer, for an image taken in year 2016 (pre-removal) 


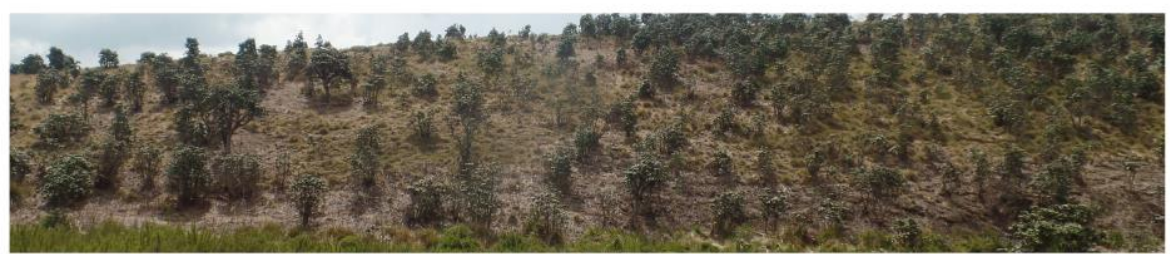

Photo by: D. Jayasekara 07.04.2017 - Post Removal

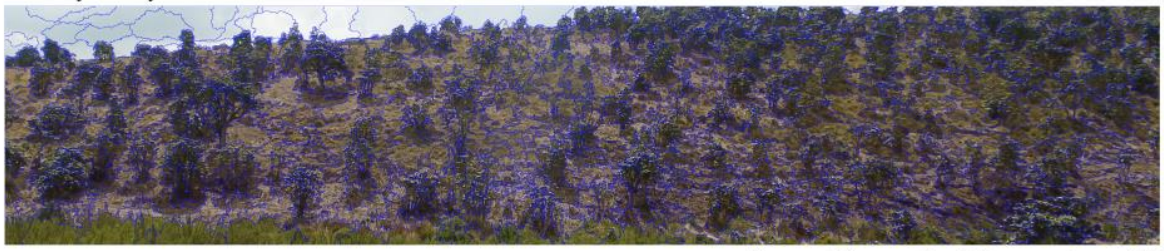

Segmentation - scale: 100 , compactness: 0.5

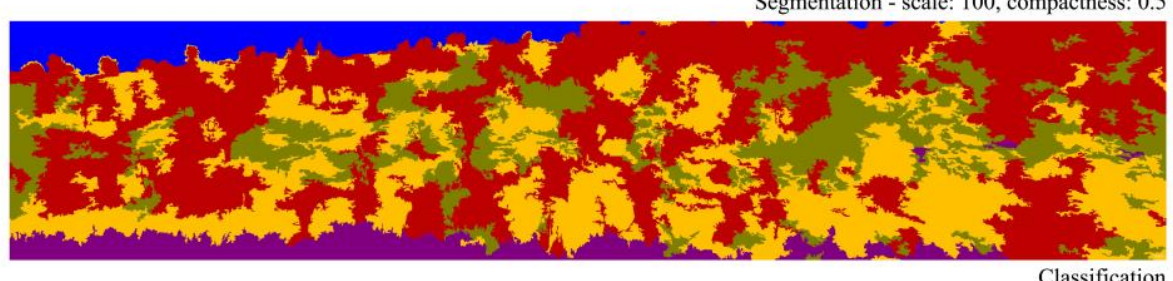

Classification

Rhododendron arboreum - Grasses - $17.5 \%$ Sky $-7.3 \%$ $40.7 \%$

Bare ground $-26.8 \%$

Other vegetation - $7.7 \%$

Figure 6. Photo-point (PP) images and results from image segmentation (multi-resolution) and object classification using the object-oriented techniques with the software eCognition Developer, for an image taken in year 2017 (post-removal) following the removal program of U. europaeus
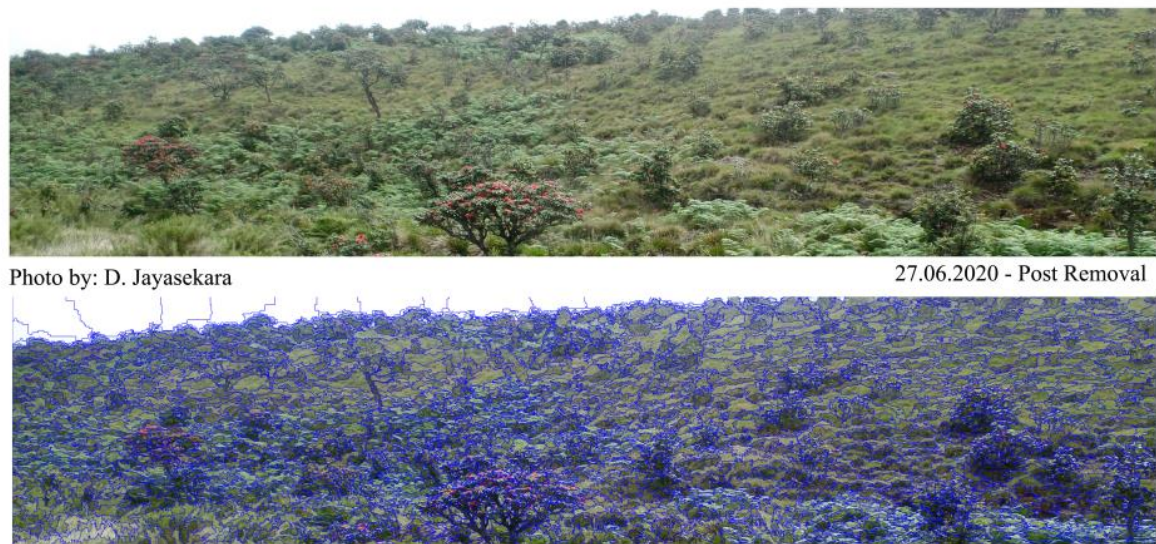

Segmentation - Scale: 150 , Compactness: 0.5

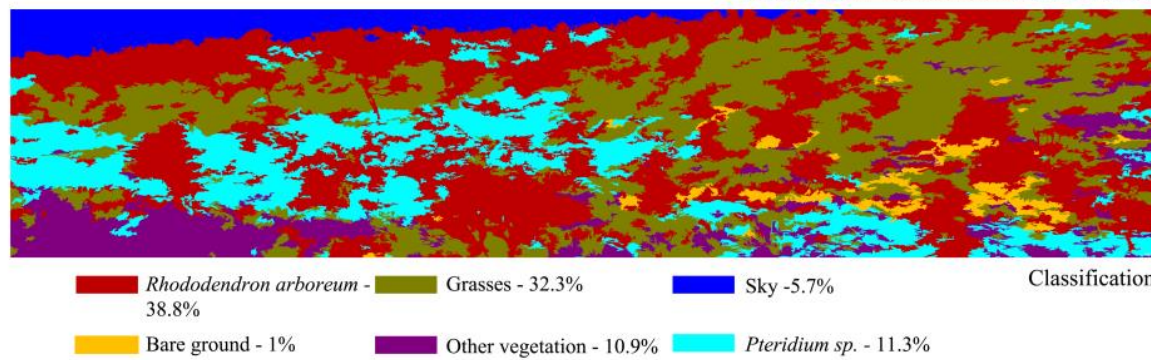

Figure 7. Photo-point (PP) images and results from image segmentation (multiresolution) and object classification using the object-oriented techniques with the software eCognition

Developer, for an image taken in year 2020 (post-removal) 


\section{Discussion}

This study is a comprehensive example of the impacts of invasive species in nonnative landscapes. While most of the biological invasions are considered to be threatening the native communities, the long-term establishment of invasive species cause more complex scenarios where invasive species management could be more challenging. $U$. europaeus had been rapidly invading the native grassland vegetation in one area of the park growing as a large continuous stand (Somaweera et al., 2012) dominating the native vegetation types. Similar observations have been recorded by (Cordero et al., 2016) in a subtropical forest-grassland mosaic habitat in Brazil. It was competing with the native grasses and $R$. arboreum growing in a scattered distribution. However, some of the U. europaeus shrubs were observed to be growing successfully near the neighboring $R$. arboreum plants. The Rubes $s p$. which is a herbaceous thorny creep-like shrub was also found growing together with this combination. Therefore, the mutual benefits shared by these plants are yet to be discovered if there is any. According to Leary et al. (2006), U. europaeus, being a leguminous plant, involves in symbiotic nitrogen fixation and deplete the soil nutrient levels via soil acidification which gives it a competitive advantage over the native grass species. Meanwhile, Pethiyagoda (2012) mentioned that the acidic soil can benefit $R$. arboreum and several other plants. The results of our study reveal similar observations where the growth of grasses was depleted during the pre-eradication period and unaffected $R$. arboreum plants.

The pre-removal and post-removal 1 densities of $U$. europaeus suggest that the removal program carried out in 2016-2017 was successful to a greater extent in the short term. However, after few months of shrub removal, small bushes that survived the removal program and newly emerging vegetative parts (probably from the buried dormant seeds) (Fig. 8) could be observed despite the park management efforts of continuous removal with the help of the available labor. The considerable increase in $U$. europaeus density in the post-removal 2 period in 2021 indicates the high regenerating capacity of the plant. De Alwis et al. (2019) have reported an increase in the regeneration of $U$. europaeus within six months of removal similar to our observations. It is interesting to see how long these seeds will keep producing young buds. If it lasts for a longer time extent of close to 30 years as the literature suggests (Hill et al., 2001), the mechanical removal of plants will cost a large amount of labor hours and time to achieve a complete and successful eradication of this invasive plant. Therefore, the viability of mechanical removal programs needs to be studied further. Moreover, we doubt that other control methods such as herbicides, fire and biological control used in other parts of the world (Rolston and Talbot, 1980; Hill et al., 2001, 2008; Rees and Hill, 2001; Cooper and Summers, 2010; Herrera-Reddy et al., 2012; Mbatha, 2016) can be applicable to the highly sensitive ecosystems of HPNP. It lefts, continuous mechanical removal (uprooting), the only option of controlling this invasive plant in these habitats. However, lack of available human labor and funds makes it difficult for the park management to continue the eradication programs for extended periods, which in turn has resulted in newly emergent plants reaching maturity producing flowers and contributing more seeds to the seed banks. The natural stream system of the park helps the dispersal of the seeds (Pethiyagoda, 2012).

U. europaeus provided the ideal hunting habitats for the predatory lizard C. nigrilabris which favors areal insect pollinators as its prey. Therefore, numerous species of bees and butterflies that were attracted to the yellow flowers of $U$. europaeus were frequently captured by the green colored $C$. nigrilabris camouflaging in the thorny branches of this 
invasive shrub. This beneficial relationship for $C$. nigrilabris has been observed by Somaweera et al. (2012) and Jayasekara et al. (2017, 2019). Following the eradication of $U$. europaeus, the drastic decline observed in C. nigrilabris density should be largely due to the reduced prey availability (insect pollinators) as a result of the removal of $U$. europaeus shrubs. It was the most preferred microhabitat of $C$. nigrilabris for a number of other behaviors as well (Jayasekara et al., 2017, 2019). Especially, the loss of protection provided by thorny $U$. europaeus shrubs against the areal predators (Somaweera et al., 2012) may have made the lizards become more vulnerable to Jungle crow and other predators (de Silva, 2007; Karunarathna and Amarasinghe, 2008; Chandrasiri et al., 2017). Furthermore, more investigations are required to track a possible local migration by lizards back into ecotone between the Cloud Forest and the Grassland which can be considered the natural habitat of the species before the introduction of $U$. europaeus to this region. Previous density estimates of C. nigrilabris by Erdelen (1988) and Somaweera et al. (2012) were extremely high (>200 individuals/ha). However, according to the most recent population study (Jayasekara et al., 2020) the overall density of $C$. nigrilabris has largely decreased by the year 2019. In addition to $C$. nigrilabris, a pair of another agamid species Cophotis ceylanica (Fig. 3c) which was considered to be strictly Cloud Forest adapted was observed from a bush of $U$. europaeus in the middle of the grassland habitat. This is the first and only finding of Co. ceylanica within the grassland habitat of HPNP. They were perching in the same $U$. europaeus plant during all three preeradication survey months. Unlike $C$. nigrilabris, Co. ceylanica was camouflaging on the brown colored dead branches of $U$. europaeus which better suits its coloration. However, with the removal of the U. europaeus plants, they were no more to be observed after the eradication programs. This unexpected observation was another example of faunal species being attracted towards $U$. europaeus by its special characteristics.

When the pollinator abundance is considered, only the order Hymenoptera displayed a considerable decline while the Lepidoptera abundance was more or less closer to the pre-eradication figure. Bees hovering around the flowers of $U$. europaeus were a frequent site during the pre-eradication period. Unlike the native flowers of the Cloud Forest which bloom mostly in annual cycles, U. europaeus was flowering almost throughout the year attracting the bees for its pollen. With the removal of $U$. europaeus the sudden drop in the Hymenopteran abundance was evident due to the lack of pollen bearing flowers in the grassland habitat. Therefore, it can be considered another consequence of the eradication program which reduces an important source of the bee hives. The native counterpart which fulfills the same niche has not been clearly identified yet. However, some plant species of the neighboring habitat of Cloud Forest may benefit by the absence of $U$. europaeus. Interestingly, order Lepidoptera did not show much fluctuation in abundance in the two time periods considered. It can be concluded that butterflies in general were not benefitted by the presence of $U$. europaeus since it is not a good nectar source and due to high predator pressure within the open grasslands. However, Pea blue butterfly L. boeticus was recorded during the arial-netting. It has been recorded that this species uses $U$. europaeus as a larval feeding plant (Jayasinghe et al., 2014).

Moreover, the removal of $U$. europaeus increases the pasture availability for the Samba deer population of the park providing space for the grass species to grow. This can be clearly observed in the PP analysis. Similar to observations of De Alwis et al. (2019), the early regenerating layer includes species such as $G$. exaristata and Pennisetum clandestinum. Despite being a prominent food source for Sambar deer 
(Padmalal et al., 2003) P. clandestinum is considered an introduced exotic grass. Our observations up to two years of post-removal show that alongside the grasses, another possible invasive plant genus in the habitat, Pteridium spp., were gaining their ground in the succession stage. This process is facilitated by the reduced soil $\mathrm{pH}$ level due to $U$. europaeus. The genus Pteridium is considered to be toxic to the animals as well as humans (Smith, 2020). If the abundance of Pteridium spp. increases, there is a potential threat for the Sambar deer population of the park.
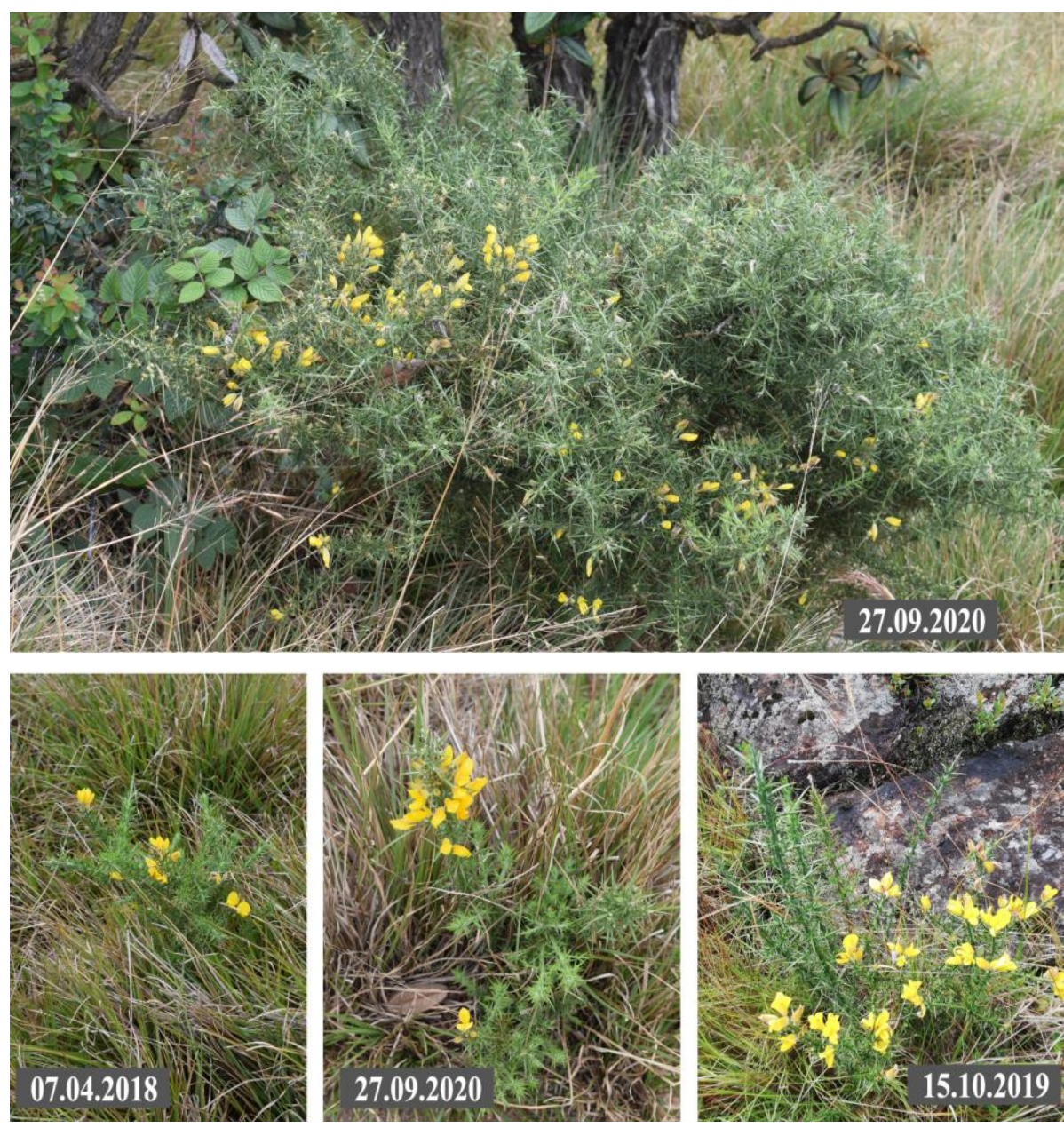

Figure 8. Newly emerged young U. europaeus shrubs already bearing flowers (all photos captured after March 2018, capture dates are embedded in photos)

After the introduction of $U$. europaeus to the Horton Plains in the British ruling period in the $19^{\text {th }}$ century, C. nigrilabris has probably migrated to the grassland areas from the adjacent Cloud Forest and ecotone as an adaptive behavioral strategy. This explains the adaptive nature of this lizard species. It was until the findings of this survey one of the remaining two lizard species in the region had also migrated to the grassland habitat (Co. ceylanica). C. nigrilabris had been well adapted to utilize the novel beneficial conditions generated by human interventions to the habitat structure. However, in the event of the sudden loss of its preferred microhabitat, the grassland population of $C$. nigrilabris experienced a drastic decline in density as a negative impact of $U$. europaeus removal. Therefore, further monitoring and assessment of 
population status are suggested to minimize the impact caused on this endemic lizard species by the recently implemented park management strategies. Despite the regeneration of $U$. europaeus, the density of grassland $C$. nigrilabris is in a steep declining trend according to our latest observations of 2021.

The insect pollinators play a major role in the plant pollination. Among those, order Hymenoptera can be considered the most important group of pollinators to which the bees belong (Losey and Vaughan, 2006; Ollerton et al., 2011; McCravy, 2018). Furthermore, pollination by bees is highly important for the diversity of plant communities since bees can be considered as the pollinator group that pollinate the greatest number of plant species in the world. With the eradication of $U$. europaeus, we predict a probable decline in bee populations of HPNP, at least in short term. However, the declining of $C$. nigrilabris which was used to be preying on bees and other insects will inversely relate with bee abundance in the grasslands. The increased Hymenoptera abundance by the sampling year 2021 indicates the above fact.

Based on our results, continuous mechanical removal of $U$. europaeus is the most effective management measure that is suitable for a sensitive area like HPNP. We recommend conducting removal programs continuously in time intervals of at least 6 months based on our results as well as observations of De Alwis et al. (2019). Intensive management interventions up to 5 years and continuous monitoring and control up to 20 years as suggested by Cooper and Summers (2010) would improve the management programs in the long term. Prevention of fires in the area should be given a high concern since the previous studies indicate that dormant seeds of $U$. europaeus could be activated following the exposure to high heat (Lee et al., 1986). Even though the fires have not been recorded in recent past, with the high visitor pressure in the park, the potential risk of fire is always present especially during drier months. Moreover, mechanical removal being the only applicable solution will make the $U$. europaeus eradication programs of HPNP much more difficult when compared to other programs of the world.

\section{Conclusions}

Based on the findings of this study, there were both positive and negative impacts of eradication programs of $U$. europaeus. When the long-term conservation targets are considered, it can be argued that invasive species like $U$. europaeus should be eliminated from their nonnative habitats. Furthermore, the invasive nature of the plant species itself poses a threat of unbalancing the ecosystem and community structure. The scenario observed with particularly $C$. nigrilabris and bees gives the message of implementing correct and timely conservation and management practices before the invasive species cause irreversible changes to the habitat and community. If $U$. europaeus was eliminated from the habitat in its early stages of invasion, it would not have affected the endemic and threatened lizard $C$. nigrilabris or the pollinators. Therefore, the early detection and removal of invasive species is vital for reducing their ecological impact. However, once the installation is done and the changes are irreversible, the costs and benefits of eradication must be carefully weighed before undertaking a large-scale enterprise. We highly recommend considering the possible relocation of sensitive species like $C$. nigrilabris and Co. ceylanica prior to engaging in future removal programs. Park management should continue strict fire prevention protocols and visitor awareness should be increased. The controlled burning of removed 
plants should also be carried out under strict guidelines since burning plots could become potential future nurseries for $U$. europaeus. There is the need of research focused on identifying ecologically less damaging and more viable removal methods that could be implemented in highly sensitive areas like HPNP.

Acknowledgements. We would like to express our gratitude to the University of Sri Jayewardenepura and the Department of Zoology for the facilities granted and for providing financial support to conduct this research. We appreciate the generous corporation of Mr. Pradeep Kumara (Warden, HPNP) and the Horton Plains National Park staff. We acknowledge the "Department of Wildlife Conservation" for granting permission (Permit No: WL/3/2/12/15, WL/3/2/9/16) to conduct this research. We extend our gratitude to Dr. Anslem de Silva and Dr. Kanishka Ukuwela for providing valuable literature/insights and IDEA WILD for providing us field instruments which were of great value during field excursions. Dushantha Jayakody, Bhasarani Navoda and Suweesha Amarakoon who supported us in and off the field are also acknowledged. Authors would like to thank all the reviewers and editors for their valuable comments and suggestions.

Conflict of interests. The authors have declared that no competing interests exist.

Data availability. The authors confirm that all data underlying the findings are available upon request.

Funding. This work was supported by the University Grants (USJ) of University of Sri Jayewardenepura under the grant [ASP/01/RE/SCI/2015/23].

\section{REFERENCES}

[1] Atlan, A., Barat. M., Legionnet, A. S., Parize, L., Tarayre, M. (2010): Genetic variation in flowering phenology and avoidance of seed predation in native populations of Ulex europaeus. - Journal of Evolutionary Biology 23(2): 362-371.

[2] Baatz, M. (2000): Multi resolution segmentation: an optimum approach for high quality multi scale image segmentation. - Beiträge zum AGIT-Symposium. Salzburg (Austria) 2000. Wichmann, Heidelberg, pp. 12-23.

[3] Baatz, M., Benz, U., Dehghani, S., Heynen, M., Holtje, A., Hofmann, P., Lingenfelder, I., Mimler, M., Sohlbach, M., Weber, M., Willhauck, G. (2004): eCognition Professional User Guide, version 4.0. - Definiens Imaging GmbH, Munich (Germany).

[4] Bambaradeniya, C. N. (2002): The status and implications of alien invasive species in Sri Lanka. - Zoos' Print Journal 17(11): 930-935.

[5] Barney, J. N., Tekiela, D. R., Dollete, E. S., Tomasek, B. J. (2013): What is the "real" impact of invasive plant species? - Frontiers in Ecology and the Environment 11(6): 322329.

[6] Bowman, G., Tarayre, M., Atlan, A. (2007): How is the invasive gorse Ulex europaeus pollinated during winter? A lesson from its native range. - Plant Ecology 197(2): 197206.

[7] Buckland, S. T., Goudie, I. B. J., Borchers, D. L. (2000): Wildlife population assessment: past developments and future directions. - Biometrics 56(1): 1-12.

[8] Buckland, S. T., Anderson, D. R., Burnham, K. P., Laake, J. L., Borchers, D. L., Thomas, L. (2001): Introduction to Distance Sampling: Estimating Abundance of Biological Populations. - Oxford University Press, New York.

[9] Buckland, S. T., Anderson, D. R., Burnham, K. P., Laake, J. L., Borchers, D. L., Thomas, L. (2004): Advanced Distance Sampling. Vol. 2. - University Press, Oxford.

[10] Byers, J. E., Reichard, S., Randall, J. M., Parker, I. M., Smith, C. S., Lonsdale, W. M., Atkinson, I. A. E., Seastedt, T. R., Williamson, M., Chornesky, E., Hayes, D. (2002): Directing research to reduce the impacts of nonindigenous species. - Conservation Biology 16(3): 630-640. 
[11] Chandrasiri, S. P., Dharmarathne, W. D. S. C., Lakmal, S., Mahaulpatha, W. A. D. (2017): Distribution of the jungle crow (Corvus levaillantii Lesson, 1831) and their potential threats to biodiversity in Horton Plains National Park, Sri Lanka. - Wildlanka 5(2): 073-077.

[12] Christina, M., Limbada, F., Atlan, A. (2020): Climatic niche shift of an invasive shrub (Ulex europaeus): a global scale comparison in native and introduced regions. - Journal of Plant Ecology 13(1): 42-50.

[13] Clements, D. R., Petersonm, D. J., Prasad, R. (2001): The biology of Canadian weeds. 112. Ulex europaeus L. - Canadian Journal of Plant Science 81(2): 325-337.

[14] Cooper, J., Summers, N. (2010): Development of strategies for the eradication of gorse (Ulex europaeus L.) at a wind farm construction site in North-East Tasmania. - 17th Australasian Weeds Conference. New Frontiers in New Zealand: Together We Can Beat the Weeds. - New Zealand Plant Protection Society. Christchurch, New Zealand, pp. 111-112.

[15] Cordero, R. L., Torchelsen, F. P., Overbeck, G. E., Anand, M. (2016): Invasive gorse (Ulex europaeus, Fabaceae) changes plant community structure in subtropical forestgrassland mosaics of southern Brazil. - Biological Invasions 18(6): 1629-1643.

[16] Cruz, M. H. M., Aldaco, A. S., Cano, L. A. M., Rodríguez, M. L., Vázqueza, M. A. R., Reyes, L. M. A., Martínez, E. C., Rosas, O. G. P., Espejo, L. R., Secundino, J. A. F., Martínez, J. L. R. (2016): New generation of the multimedia search engines. - Optics and Photonics for Information Processing X, International Society for Optics and Photonics (9970): 99700V.

[17] De Alwis, S., Perera, S. J., Kudavidanage, E. P., Wijesundara, S. (2019): Quantification of habitat regeneration after removing invasive plant Ulex Europaeus in Horton Plains National Park. - 7th International Conference of Sabaragamuwa University of Sri Lanka (ICSUSL), Belihuloya.

[18] De Silva, A. (2007): The Diversity of Horton Plains National Park: With Special Reference to its Herpetofauna and Including a Bibliography on the Literature on Horton Plains. - Vijitha Yapa Publications, Sri Lanka.

[19] De Silva, A., Ukuwela, K. (2017): A Naturalist's Guide to the Snakes \& Other Reptiles of Sri Lanka. - John Beaufoy Publishing Limited, Oxford, UK.

[20] Dharmarathne, W. D. S. C., Mahaulpatha, W. A. D. (2018): Foraging behavior of endemic dull-blue flycatcher (Eumyias sordidus) in tropical montane cloud forest habitats of Sri Lanka. - International Journal of Science and Research 7(2): 111-118.

[21] DWC (2007): Biodiversity Baseline Survey: Horton Plains National Park. Consultancy Services Report prepared by Green, M. J. B. (ed.), De Alwis, S. M. D. A. U., Dayawansa, P. N., How, R., Singhakumara, B. M. P., Weerakoon, D. and Wijesinghe, M. R. - ARD Inc in association with Infotech IDEAS and GREENTECH Consultants. Sri Lanka Protected Areas Management and Wildlife Conservation Project (PAM\&WCP/CONSULT/02/BDBS). Department of Wildlife Conservation, Ministry of Environment and Natural Resources, Colombo, pp. 1-40.

[22] eCognition Developer T (2014): 9.0 User Guide. - Trimble GmbH, Munich.

[23] Erdelen, W. (1988): Population dynamics and dispersal in three species of Agamid lizards in Sri Lanka: Calotes calotes, C. versicolor and C. nigrilabris. - Journal of Herpetology 22: 42-52.

[24] Gaitonde, N., Joshi, J., Kunte, K. (2018): Evolution of ontogenic change in color defenses of swallowtail butterflies. - Ecology and Evolution 8(19): 9751-9763.

[25] Gaynor, D. L., MacCarter, L. E. (1981): Biology, ecology, and control of gorse (Ulex europaeus): a bibliography. - New Zealand Journal of Agricultural Research 24(1): 123137.

[26] Gerber, E., Krebs, C., Murrell, C., Moretti, M., Rocklin, R., Schaffner, U. (2008): Exotic invasive knotweeds (Fallopia spp.) negatively affect native plant and invertebrate assemblages in European riparian habitats. - Biological Conservation 141(3): 646-654. 
[27] Gonzalez, M., Mathieu, A., Augusto, L., Gire, C., Bakker, M. R., Budynek, A. (2010): Gorse seed bank variability in maritime pine stands. - Seed Science Research 20: 31-38.

[28] Grootaert, P., Pollet, M., Dekoninck, W., Van Achterberg, C. (2010): Sampling Insects: General Techniques, Strategies and Remarks. - In: Eymann, J., Degreef, J., Hāuser, C., Monje, J. C., Samyn, Y., Vanden Spiegel, D. (eds.) Manual on Field Recording Techniques and Protocols for All Taxa Biodiversity Inventories and Monitoring. Abc Taxa, Belgium, pp. 337-399).

[29] Gunatilleke, C. V. S., Gunatilleke, I. A. U. N. (1986): Horton Plains: some aspects of its vegetation and ecology. - Sri Lanka WildI 3(4): 9-11.

[30] Harris, R. J., Toft, R. J., Dugdale, J. S., Williams, P. A., Rees, J. S. (2004): Insect assemblages in a native (Kanuka-Kunzea ericoides) and an invasive (gorse-Ulex europaeus) shrubland. - New Zealand Journal of Ecology 28(1): 35-47.

[31] Hermann, R. K., Newton, M. (1968): Tree Planting for Control of Gorse on the Oregon Coast. - School of Forestry, Oregon State University, Corvallis, OR.

[32] Herrera-Reddy, A. M., Carruthers, R. I., Mills, N. J. (2012): Integrated management of Scotch broom (Cytisus scoparius) using biological control. - Invasive Plant Science and Management 5(1): 69-82.

[33] Hill, R. L., Gourlay, A. H., Fowler, S. V. (2000): July. The biological control program against gorse in New Zealand. - Proceedings of the $\mathrm{X}$ international Symposium on Biological Control of Weeds (Bozeman), Montana State University, Montana, USA, pp. 909-917.

[34] Hill, R. L., Gourlay, A. H., Barker, R. J. (2001): Survival of Ulex europaeus seeds in the soil at three sites in New Zealand. - New Zealand Journal of Botany 39(2): 235-244.

[35] Hill, R. L., Gourlay, A. H. (2002): Host-range testing, introduction, and establishment of Cydia succedana (Lepidoptera: Tortricidae) for biological control of gorse, Ulex europaeus L., in New Zealand. - Biological Control 25: 173-186.

[36] Hill, R. L., Ireson, J., Sheppard, A. W., Gourlay, A. H., Norambuena, H., Markin, G. P., Kwong, R., Coombs, E. M. (2008): A global view of the future for biological control of gorse, Ulex europaeus L. - XII International Symposium on Biological Control of Weeds. Centre for Agriculture and Biosciences International, Wallingford, UK, pp. 680686.

[37] Hill, R. L., Sandrey, R. A. (1986): The costs and benefits of gorse. - Proceedings, New Zealand Weed and Pest Control Conference, Hastings (New Zealand) 1986. New Zealand Weed and Pest Control Society, New Zealand, pp. 70-73.

[38] Hobbs, R. J., Higgs, E., Harris, J. A. (2009): Novel ecosystems: implications for conservation and restoration. - Trends in Ecology \& Evolution 24(11): 599-605.

[39] Holm, L. G., Plucknett, J. V., Herberger, J. P. (1977): The World's Worst WeedsDistribution and Biology. - The University of Hawaii Press, Honolulu, HI.

[40] Hoshovsky, M. (1989): Element Stewardship Abstract for Ulex Europaeus. - The Nature Conservancy, Arlington, VA.

[41] Ireson, J. E., Gourlay, A. H., Holloway, R. J., Chatterton, W. S., Foster, S. D., Kwong, R. M. (2008): Host specificity, establishment and dispersal of the gorse thrips, Sericothrips staphylinus Haliday (Thysanoptera: Thripidae), a biological control agent for gorse, Ulex europaeus L. (Fabaceae), in Australia. - Biological Control 45: 460-471.

[42] James, J. J., Smith, B. S., Vasquez, E. A., Sheley, R. L. (2010): Principles for ecologically based invasive plant management. - Invasive Plant Science and Management 3(3): 229-239.

[43] Jayasekara, E. G. D. P., Prabhath, M. C., Mahaulpatha, W. A. D. (2017): Behaviour Associated with Habitat Utilization of Endangered Black-Cheek Lizard (Calotes nigrilabris) in the Grasslands of Horton Plains National Park in Sri Lanka. - Proceedings of the 22nd International Forestry and Environment Symposium, Colombo (Sri Lnaka), Department of Forestry and Environmental Science (University of Sri Jayewardenepura, Sri Lanka. 
[44] Jayasekara, E. G. D. P., Prabhath, M. C., Mahaulpatha, W. A. D. (2019): Microhabitat utilisation of endemic lizard Calotes nigrilabris in the grasslands of Horton Plains National Park, Sri Lanka. - Journal of Tropical Forestry and Environment 9(1): 59-68.

[45] Jayasekara, D., Keerthirathna, L., Mahaulpatha, D. (2020): Population densities and conservation assessment of three threatened agamid species in Horton Plains National Park, Sri Lanka. - Journal of Wildlife and Biodiversity 4(3): 70-79.

[46] Jayasinghe, H., Rajapaksha, S., De Alwis, C. (2014): A compilation and analysis of food plants utilization of Sri Lankan butterfly larvae (Papilionoidea). - TAPROBANICA: The Journal of Asian Biodiversity 6(2): 110-131.

[47] Karsten, K. B., Andriamandimbiarisoa, L. N., Fox, S. F., Raxworthy, C. J. (2009): Population densities and conservation assessments for three species of chameleons in the Toliara region of south-western Madagascar. - Amphibia-Reptilia 30: 341-350.

[48] Karunarathna, D. M. S. S., Amarasinghe, A. A. T. (2008): An observation of the Jungle Crow (Aves: Corvidae) feeding on Ceylon Pygmy Lizards, Cophotis ceylanica (Reptilia: Agamidae) at Horton Plains NP in Sri Lanka. - Sauria 30(4): 59-62.

[49] Kissa, D. O., Sheil, D. (2012): Visual detection based distance sampling offers efficient density estimation for distinctive low abundance tropical forest tree species in complex terrain. - Forest Ecology and Management 263: 114-121.

[50] Leary, J. K., Hue, N. V., Singleton, P. W., Borthakur, D. (2006): The major features of an infestation by the invasive weed legume gorse (Ulex europaeus) on volcanic soils in Hawaii. - Biology and Fertility of Soils 42(3): 215-223.

[51] Lee, W. G., Allen, R. B., Johnson, P. N. (1986): Succession and dynamics of gorse (Ulex europaeus L.) communities in the dunedin ecological district South Island, New Zealand. - New Zealand Journal of Botany 24: 279-292.

[52] Lodge, D. M., Williams, S., MacIsaac, H. J., Hayes, K. R., Leung, B., Reichard, S., Mack, R. N., Moyle, P. B., Smith, M., Andow, D. A., Carlton, J. T. (2006): Biological invasions: recommendations for US policy and management. - Ecological Applications 16(6): 2035-2054.

[53] Losey, J. E., Vaughan, M. (2006): The economic value of ecological services provided by insects. - Bioscience 56(4): 311-323.

[54] Lowe, S., Browne, M., Boudjelas, S., De Poorter, M. (2000): 100 of the World's Worst Invasive Alien Species: A Selection from the Global Invasive Species Database. Vol. 12. - Invasive Species Specialist Group, Auckland, New Zealand.

[55] MA (Millennium Ecosystem Assessment) (2005): Ecosystems and Human Well-Being: Synthesis. - Island Press, Washington, DC.

[56] Marambe, B., Bambaradeniya, C., Kumara, D. K. P., Pallewatta, N. (2001): Human Dimensions of Invasive Alien Species in Sri Lanka. - In: McNeely, J. A. (ed.) The Great Reshuffling: Human Dimensions of Invasive Alien Species. IUCN, Cambridge, UK, pp. 135-144.

[57] Mbatha, P. M. (2016): Scotch broom (Cytisus scoparius (L.) Link) and gorse (Ulex europaeus L.) in South Africa: an assessment of invasiveness, management options and feasibility for countrywide eradication. - Master of Science Dissertation, University of KwaZulu-Natal, Westville.

[58] McCravy, K. W. (2018): A review of sampling and monitoring methods for beneficial arthropods in agroecosystems. - Insects 9(4): 170.

[59] McNeely, J. A. (ed.) (2001): The Great Reshuffling: Human Dimensions of Invasive Alien Species. - IUCN, Gland, Switzerland and Cambridge, UK.

[60] Michel, P., Mathieu, R., Mark, A. F. (2010): Spatial analysis of oblique photo-point images for quantifying spatio-temporal changes in plant communities. - Applied Vegetation Science 13(2): 173-182.

[61] Morales, C. L., Traveset, A. (2009): A meta-analysis of impacts of alien vs. native plants on pollinator visitation and reproductive success of co-flowering native plants. - Ecology Letters 12: 716-728. 
[62] Nentwig, W. (2007): Pathways in plant invasions. - Ecological Studies 193: 51-66.

[63] Ollerton, J., Winfree, R., Tarrant, S. (2011): How many flowering plants are pollinated by animals? - Oikos 120(3): 321-326.

[64] Padmalal, U., Takatsuki, S., Jayasekara, P. (2003): Food habits of Sambar Cervus unicolor at the Horton Plains National Park, Sri Lanka. - Ecological Research 18: 775782.

[65] Pethiyagoda, R. (2012): Horton Plains: Sri Lanka's Cloud-Forest National Park. Wildlife Heritage Trust, Colombo, Sri Lanka.

[66] Rees, M., Hill, R. L. (2001): Large-scale disturbances, biological control and the dynamics of gorse populations. - Journal of Applied Ecology 38: 364-377.

[67] Rodriguez, L. F. (2006): Can invasive species facilitate native species? Evidence of how, when, and why these impacts occur. - Biological Invasions 8(4): 927-939.

[68] Rolston, M. P., Talbot, J. (1980): Soil temperatures and regrowth of gorse burnt after treatment with herbicides. - New Zealand Journal of Experimental Agriculture 8(1): 5561.

[69] Sixtus, C. R., Hill, G. D., Scott, R. R. (2003): The effect of temperature and scarification method on gorse (Ulex europaeus L.) germination. - New Zealand Plant Protection 56: 201-205.

[70] Smith, B. L. (2020): The toxicity of bracken fern (genus Pteridium) to animals and its relevance to man. - In: D'Mello, F. (ed.) Handbook of Plant and Fungal Toxicants. CRC Press, Boca Raton, pp. 63-76.

[71] Somaweera, R., Somaweera, N. (2009): Lizards of Sri Lanka: A Colour Guide with Field Keys. - Edition Chimaira, Frankfurt.

[72] Somaweera, R., Wijayathilaka, N., Bowatte, G. (2012): Does the invasive shrub Ulex europaeus benefit an endemic Sri Lankan lizard. - Herpetological Conservation and Biology 7: 219-226.

[73] Thomas, L., Buckland, S. T., Rexstad, E. A., Laake, J. L., Strindberg, S., Hedley, S. L., Bishop, J. R., Marques, T. A., Burnham, K. P. (2010): Distance software: design and analysis of distance sampling surveys for estimating population size. - Journal of Applied Ecology 47(1): 5-14.

[74] Vilà, M., Espinar, J. L., Hejda, M., Hulme, P. E., Jarošík, V., Maron, J. L., Pergl, J., Schaffner, U., Sun, Y., Pyšek, P. (2011): Ecological impacts of invasive alien plants: a metaanalysis of their effects on species, communities and ecosystems. - Ecology Letters 14: 702-708.

[75] Viljoen, B. D., Stoltsz, C. W. (2007): Evaluation of selected herbicides for the control of European gorse (Ulex europaeus L) by cut-stump and foliar treatment. - South African Journal of Plant and Soil 24: 130-132.

[76] Wijesundera, D. S. A. (1999): Alien Invasive Plants of Sri Lanka and Their History. - In: Marambe, B. (ed.) Proceedings of First National Workshop on Alien Invasive Species of Sri Lanka. Section D, Vol. 3. Ministry of Forestry and Environment and SLAAS, Colombo, Sri Lanka.

[77] Williams, J. A., West, C. J. (2000): Environmental weeds in Australia and New Zealand: issues and approaches to management. - Austral Ecology 25: 425-444.

[78] Zielke, K., Boateng, J., Caldicott, N., Williams, H. (1992): Broom and Gorse: A Forestry Perspective Problem Analysis. - British Columbia Ministry of Forests, Queen's Printer, Victoria, BC. 